\title{
Survey of ethno-veterinary medicinal plants in Melkabello District, Eastern Harerghe Zone, Eastern Ethiopia
}

\author{
Chala Mohammed ${ }^{1}$, Dereje Abera ${ }^{1^{*}}$, Mezene Woyessa ${ }^{1}$ and Tadesse Birhanu ${ }^{1}$ \\ ${ }^{1}$ School of Veterinary Medicine, Collage of Medical and Health Science, Wollega University, P.O. \\ Box 395 Nekemte, Ethiopia \\ *Correspondent author: School of Veterinary Medicine, Collage of Medical and Health Science, \\ Wollega University, P. O. Box 395, Nekemte Ethiopia, Email: dejabera@gmail.com and drbirhan@ \\ yahoo.com \\ http://dx.doi.org/10.4314/evj.v20i2.1
}

\begin{abstract}
An ethno botanical survey was conducted from November 2014 to April 2015 in Melkabello district, Eastern Harerghe Zone, Oromia Regional State of Ethiopia. The objectives of the study were designed to document ethno veterinary medicinal plants and identify their associated threats. A structured and pre tested questionnaire was used to collect the required data. About 20 traditional healers were purposively selected based on the recommendation of local authorities. The majority of the healers were male, 16 (80\%) and the remained 4 (20\%) were females. In this study about 68 medicinal plant species belonging to 55 families were identified in the study area. The principal sources of the medicinal plants were from wild, cultivated and both with the proportion of $53(77.9 \%), 12(17.6 \%)$ and $3(4.4 \%)$, respectively. In this study herb, 27 (39.7\%) followed by tree, 19 $(27.9 \%)$ were the most commonly used habits of the plants by traditional healers. The major plant parts used were leaf, 40 (58.8\%) and bark, 2 (2.9\%). The most common administration routes were oral, 48 (70.6\%) followed by topical, $12(17.6 \%)$ and aerosol 3(4.4\%). Febrile diseases, gastrointestinal disorders, external injuries, blackleg and reproductive insufficiency were treated by the traditional practioners. In conclusion, the study revealed that participants had a good knowledge to treat livestock ailments, but the dose varies among the healers. Therefore, further study should be conducted to evaluate the efficacy and standardize the dose of medicinal plants in the study area.
\end{abstract}

Keywords: Ailments, Eastern Harerghe Zone, Ethiopia, Ethno-Veterinary, Medicinal Plants 


\section{Introduction}

In Ethiopia plant remedies are still the most important and sometimes the only sources of therapeutics for nearly $80 \%$ of human and more than $90 \%$ in livestock population. A great variety of traditional plants are used to treat and prevent livestock health problems and medicinal plants which have been used both for prevention and cure of various diseases of humans and animals from time immemorial occupy the largest portion(Gebrehiwot Mengistu, 2004).

Despite that the traditional healers are the best sources of information about the knowledge of the medicinal plants, it was found very difficult to assure their indigenous knowledge. Because, it is transferred from generation to generation or ally so the knowledge of ethno-medicinal plants is on the verge of irreversible loss (Mirutse Giday et al., 2003; Tadesse Birhanu and Dereje Abera, 2015). Still now, it is not widely used as it could be because the knowledge and skills are fragile and not well documented including Melkabello district, eastern Harerghe Zone as it is kept as a secret(Yared Yigezu et al., 2014). Therefore, the study was designed to document ethno-veterinary medicinal plant species and knowledge of the traditional health practitioners in study area.

\section{Materials and Methods}

\section{Study area}

The study was conducted from November 2014 to May 2015in Melkabello district, East Harerghe Zone of Oromia Regional State, eastern Ethiopia. The study area is found at $487 \mathrm{kms}$ of east of Addis Ababa, the capital city of the country. The average temperature in the area is $24^{\circ} \mathrm{c}$ with the average rain fall is $1800 \mathrm{~mm}$ and the altitude ranges from $1300-3140 \mathrm{~m}$ above sea level and the various topographic features of district include Dega (high land)(20\%), Woyna Dega (Mid-high land) (39\%) and kola (Lowland) (41\%) (NAMSA, 2015). In terms of livestock population 75,564 , sheep 12,708, goats 18,681 , equine 98,674, chicken and 84, 276. Podocarpus Acacia plants are the dominant vegetation of the area. Mixed farming system is the mode of agriculture in the districts in which cattle and goats play an important role for the livelihood of the local population (CSA, 2009). 


\section{Study population}

The target populations for this study were 20 voluntary traditional healers who participated and interviewed purposively based on the recommendation of local authorities of the district.

\section{Data collection methods}

Purposive sampling technique was used to select the district and study participants based on the availability of traditional healers andrecommendations of local authority. The data were collected by using a-structured and pre-tested questioner for interview, observations and field guided walks (Martin, 1995). Before collecting the data, written permission was obtained from the office of the district and permission was obtained from the administrator of each selected kebele. Following this, the purpose of the study was explained to each informant and verbal prior consent was obtained.

During the study period, each informant was visited two to three times in order to confirm the reliability of the ethno-botanical information. The responses that were not in harmony with each other were rejected. Interviews and discussions were undertaken based on checklist of questions prepared in English and translated to local language 'Afan Oromo'. Information was carefully recorded during an interview with an informant as well the knowledge of vegetation categorization which was asked and recorded. Field observations were performed with the help of local guides on the morphological features and habitats of each medicinal plant species in the field. Group discussions were conducted on ethno-veterinary medicinal plants and their threats, conservation and transferability of knowledge in the community.

\section{Plant specimen collection and identification}

The reported medicinal plants were collected from natural vegetation and home gardens during the field walks and habitats of the plants were listed. Preliminary identification was done at the site (field) and the collected voucher specimens were taken to the Haramaya University, Department of Herbarium. Specimen identification and confirmation was undertaken by using taxonomic keys and various volumes of the Flora of Ethiopia and Eritrea (Edwards et al., 2000; Hedberget al., 2006). Finally, the identified specimens were reconfirmed by a taxonomic expert and labeled specimens were stored at the Herbarium. 


\section{Data analysis}

The collected ethno-botanical data were entered into SPSS version 21 and summarized using descriptive statistical methods such as frequency and percentages.

\section{Results}

In this study, the majority of the study participants were male, $16(80 \%)$ and the remained 4 (20\%) were females. About 68 ethno-medicinal plant species belonging to55 families were identified in the area. The principal sources of the plants were from wild, cultivated and both 53 (77.9\%), 12 (17.6\%) and 3 (4.4\%), respectively. Herb, 27 (39.7\%) was the most commonly used plants by traditional healers followed by tree, $19(27.9 \%)$. The major plant parts used were leaf, $40(58.8 \%)$ and bark $2(2.9 \%)$. The most common routes of administration were oral, 48 (70.6\%) followed by topical, 12 (17.6\%) and aerosol $3(4.4 \%)$. This study indicated that gastrointestinal disorder, febrile diseases, external injuries, Blackleg (in animals), and reproductive insufficiency were treated by the traditional healers (Table 1). 
Table 1: Summary of ethno veterinary medicinal plants, diseases and diseases conditions treated local, scientific and family name of the medicinal plants from November 2014 to April 2015 in Melkabello district, eastern Harerghe zone, Ethiopia.

\begin{tabular}{|c|c|c|c|}
\hline Family name & Species name & Local name & $\begin{array}{l}\text { Livestock ailments } \\
\text { treated }\end{array}$ \\
\hline Astraceae & Cyphostemaspp & Abba korro & $\begin{array}{l}\text { Mastitis, Renal problem, } \\
\text { increase milk volume }\end{array}$ \\
\hline Lamiaceae & Clorodandrummyricoidos & Harmel & Acute mastitis, Evil eye \\
\hline Euphorbiaceae & Croton macrostachyus Hochst & Bakkannisaa & $\begin{array}{l}\text { Wound healing, Anti } \\
\text {-parasite }\end{array}$ \\
\hline Curcurbitaceae & Cucumisdipsaleus & Harrigoogee & $\begin{array}{l}\text { Abdominal discomfort, } \\
\text { bloat }\end{array}$ \\
\hline Astraceae & Vernoniaauriculifora & Tiiro & Evil eye, Wound healing \\
\hline Polygonaceae & Rumennervosun & Dhangaggoo & $\begin{array}{l}\text { Gonorrhea, Cough, liver } \\
\text { disease, }\end{array}$ \\
\hline Amarantaceae & Achayrentesaspera & Darguu & $\begin{array}{l}\text { Abdominal discomfort, } \\
\text { Febrile disease }\end{array}$ \\
\hline Spundaceae & Alophaylusabsini & Biiflee & $\begin{array}{l}\text { GIT parasite, Abdominal } \\
\text { disorder }\end{array}$ \\
\hline Scrophulariaceae & VerbascumsinaiticumBenth. & Risaarrisoowri & $\begin{array}{l}\text { Febrile causal disease, } \\
\text { heart disease, Renal } \\
\text { disease }\end{array}$ \\
\hline Liliaceae & Aloe spp. & Hargeessa & $\begin{array}{l}\text { Antipyretic, spleen and } \\
\text { liver problem }\end{array}$ \\
\hline Brassicaceae & Lepidiumsativum L. & Shifuu & $\begin{array}{l}\text { Black leg, Colic, diarrhea, } \\
\text { Bloat, internal parasite }\end{array}$ \\
\hline Anacardiaceae & Rihasvulgaris & Daboobessa & Wound healing, headache \\
\hline Sapidaceae & Dodiniaeagustifolia & Dhiddecha & Ectoparasite \\
\hline Nyctaginaceae & Commicarpussillatusmelkele & Koontama & $\begin{array}{l}\text { Febrile causal disease, } \\
\text { evil eye }\end{array}$ \\
\hline Solanaceae & SolanumdasyphyllumSchumach. & HiddiBudee & Evil eye \\
\hline Limoceae & Citruslimon & Xuuxxoo & Bloat, Antitoxic \\
\hline Euphorbiaceae & Euphorbia ampliphyllaPax & Adaamii & Black leg, \\
\hline Fabaceae & Mryinemelanopheloes & Quboo & $\begin{array}{l}\text { Retained fetal membrane, } \\
\text { mastitis }\end{array}$ \\
\hline Vitaceae & Eyphostemaeyphotalum & Gangaloota & Evil eye, Ectoparasite \\
\hline Lamiaceae & Menthaspicata & Naanaa & Renal problem \\
\hline Lamiaceae & Thymus schimperiRonn. & Xoosennoo & $\begin{array}{l}\text { Gonorrhea, Cough, liver } \\
\text { disease, }\end{array}$ \\
\hline
\end{tabular}


Chala Mohammed et al.,

\begin{tabular}{|c|c|c|c|}
\hline Family name & Species name & Local name & $\begin{array}{l}\text { Livestock ailments } \\
\text { treated }\end{array}$ \\
\hline Asteraceae & Vernoniaamygdalina & Ebichaa & $\begin{array}{l}\text { Abdominal pain } \\
\text { Mich, Febrile disease }\end{array}$ \\
\hline Fabaceae & Erythrinabrucei & Waleensuu & evil eye \\
\hline Aspergesae & Asparagesafricanus & Kammona & Anurea, Heart failure, \\
\hline Fabaceae & Pterotobiumstellatum & Qajimagurracha & wound healing \\
\hline Asteraceae & Cyphostemaspp & Barbariisaa & $\begin{array}{l}\text { Black leg, Abdominal } \\
\text { disorder }\end{array}$ \\
\hline Cypraceae & Cypresnivies & Qunnii & Deworming of equide \\
\hline Aguifliciae & Ilese mites & Mi’essaa & $\begin{array}{l}\text { Wound healing, } \\
\text { Gonherrae }\end{array}$ \\
\hline Cucurbitaceae & Memordicafoetidaschumacha & Sukee & Metritis for good flavor \\
\hline$N A$ & $N A$ & Habasooddaa & infertility, GIT disorder \\
\hline Caricaceae & Caricapapaya & Papaya & $\begin{array}{l}\text { Febrile disease, } \\
\text { Amebiasis }\end{array}$ \\
\hline Rhamnaceae & Ziziphusmauritiana & Qurquraaadii & $\begin{array}{l}\text { paralytic Cold, Vomition, } \\
\text { Endoparasite }\end{array}$ \\
\hline Fabaceae & Acacia brevispica & Hammarreessa & $\begin{array}{l}\text { Black leg, Abdominal } \\
\text { disorder }\end{array}$ \\
\hline Fabaceae & Carissa spinarum $L$ & Agamsa & $\begin{array}{l}\text { Febrile causal disease, } \\
\text { evil eye }\end{array}$ \\
\hline$N A$ & $N A$ & Atarajawwee & Abdominal disconfort \\
\hline Asclapiadaceae & Periplocalinearifocia & Buriidiimtuu & $\begin{array}{l}\text { Mastitis, evil eye, } \\
\text { increase milk volume }\end{array}$ \\
\hline Lataceae & Opuntiaticusindica & Tini & $\begin{array}{l}\text { Black leg, Mich, } \\
\text { dingetegna }\end{array}$ \\
\hline Moraceae & Ficussycomorus & Luugo & $\begin{array}{l}\text { Warts, dermatological } \\
\text { disease }\end{array}$ \\
\hline Solanaceae & Nocotanatabacum & Tobacco & snake repellent, \\
\hline Convolvulaceae & Ipomeaspps & Doobbiisaartu & Black legs, Endoparasite \\
\hline Fabaceae & Acacciatortilis & Dhiddecha & Ectoparasite \\
\hline Dacaceae & $\begin{array}{l}\text { Oleaeuropae sub Spp } \\
\text { Cuspidate }\end{array}$ & Ejersa & $\begin{array}{l}\text { Effective for } \\
\text { dermatological disease. }\end{array}$ \\
\hline Kleinae & Euphorbia & Qinciba & $\begin{array}{l}\text { Bovine TB, Eye } \\
\text { opaqueness }\end{array}$ \\
\hline Solanaceae & Withaniasomnitera & Mixmixa & $\begin{array}{l}\text { Bloat, Antitoxic, } \\
\text { Appetizer }\end{array}$ \\
\hline Urticaceae & Urerahypselodendronwedd & Saakayyee & urinating equide \\
\hline Fabaceae & Sennadidymobotiya Irwin & Sanamakki & Deworming , \\
\hline
\end{tabular}




\begin{tabular}{|c|c|c|c|}
\hline Family name & Species name & Local name & $\begin{array}{l}\text { Livestock ailments } \\
\text { treated }\end{array}$ \\
\hline Rhamnaceae & Rhammusprina ides & Geeshee & $\begin{array}{l}\text { For treatments of } \\
\text { Salmonellosis }\end{array}$ \\
\hline Boraginaceae & Cordia Africana & Waddeessa & Deworming of equide \\
\hline$N A$ & $N A$ & Baaqilharragoo & Febrile causal disease \\
\hline Braecumae & Trigonellafoerum & Hulbata & $\begin{array}{l}\text { Botulism toxin, } \\
\text { Constipation }\end{array}$ \\
\hline Rutaceae & Rutachalepen & Xalataam & $\begin{array}{l}\text { Ear pain, evil eye, heart } \\
\text { failure }\end{array}$ \\
\hline Rutaceae & $N A$ & Rahaana & Evil eye, Anti pain \\
\hline Balsaminaceae & Impatienstinctoria & Qacuu & $\begin{array}{l}\text { Effective for } \\
\text { endoparasiteGonoheria. }\end{array}$ \\
\hline Verbenaceae & Premnschimperia & Urgessaa & Wound healing \\
\hline Rutaceae & $N A$ & Masoolbaa & Appetizer, spice \\
\hline Primulaceae & Runicagranetum & Rummana & $\begin{array}{l}\text { Diarrhea, vomit ion, } \\
\text { Endoparasite }\end{array}$ \\
\hline Rosaceae & Hageriaabyssininica & Heexoo & Effective deworming \\
\hline Ulmaceae & Celtisafricana & Ceekaa & Ectoparasite \\
\hline$N A$ & Eclophytus tree & Baarsaa & $\begin{array}{l}\text { Respiratory disease, anti- } \\
\text { bacterial property }\end{array}$ \\
\hline Lamifoliumceae & Ocimumlamifolium & Daamakasee & Dingetengya, Black leg \\
\hline Cammalinaceae & Commelinastephaninachiov & Walgabbis & for fattening \\
\hline Rutaceae & Citrus sinensis & Samargeela & Ectoparasite, Coughing \\
\hline$N A$ & $N A$ & Maxxannee & Black leg \\
\hline Compositacae & EchinopskerebichoMesfin & Qorobichoo & $\begin{array}{l}\text { Black leg, Respiratory } \\
\text { disease. }\end{array}$ \\
\hline Flacourtiaceae & Oncobaspinosaforss & Jilboo & $\begin{array}{l}\text { Internal parasite, } \\
\text { Mastitis }\end{array}$ \\
\hline Apocynacea & Carrissespinarum & Hiddiire'ee & Evil eye \\
\hline Capporidae & Caparissepiarialcommelina & Rigaagaangee & Deworming of equide, \\
\hline$N A$ & $N A$ & Muchaarrabgaaraa & Snake toxin \\
\hline
\end{tabular}




\section{Preparation mode and route of administration}

The most common routes of administration were oral, 48 (70.6\%) followed by topical, $12(17.6 \%)$ and aerosol 3(4.4\%) (Table 2). This study also indicated that the traditional healers uses the medicinal plants in different forms but majorly they states the three forms fresh, dry and both forms were commonly used with in fresh forms representing the largest proportion but the dry forms was also less commonly used. Fresh, 40 (58.8\%), fresh and dry, 17 (25\%) and dry, 11 $(16.2 \%)$ were the condition of the medicinal plant usage form for preparation in the study area (Table 3).

Table 2: Administration route of the medicinal plants in Melkabello district from November 2014 to April 2015

\begin{tabular}{lcc}
\hline Rout of administration & Frequency & Percent (\%) \\
\hline Oral & 48 & 70.6 \\
Topical & 12 & 17.6 \\
Oral and topical & 5 & 7.40 \\
Aerosol & 3 & 4.40 \\
Total & 68 & 100 \\
\hline
\end{tabular}

Table 3: Summary of the condition of the medicinal plant usage form in Melkabello district from November 2014 to April 2015

\begin{tabular}{lcc}
\hline Medicinal plant condition & Frequency & Percent (\%) \\
\hline Fresh & 40 & 58.8 \\
Dry & 11 & 16.2 \\
Fresh and dry & 17 & 25.0 \\
Total & 68 & 100 \\
\hline
\end{tabular}

\section{Habit and sources of medicinal plants}

Herb, 27 (39.7\%) was the most commonly used habits of the plants by traditional healers followed tree, 19 (27.9\%). The principal sources of the medicinal plants were from wild, cultivated and both with proportion of $53(77.9 \%), 12(17.6 \%)$ and $3(4.4 \%)$, respectively (Table 4$)$. 
Table 4: Source of the ethno veterinary medicinal plants in Melkabello district from November 2014 to April 2015

\begin{tabular}{lcc}
\hline Sources of medicinal plants & Frequency & Percent (\%) \\
\hline Wild & 53 & 77.9 \\
Cultivated & 12 & 17.6 \\
Both wild and cultivated & 3 & 4.40 \\
Total & 68 & 100 \\
\hline Habits of the plants & Frequency & Percent (\%) \\
\hline Tree & 19 & 27.9 \\
Herb & 27 & 39.7 \\
Shrub & 14 & 20.6 \\
Climber & 8 & 11.8 \\
Total & 68 & 100 \\
\hline
\end{tabular}

Parts of plant remedies used for the preparation

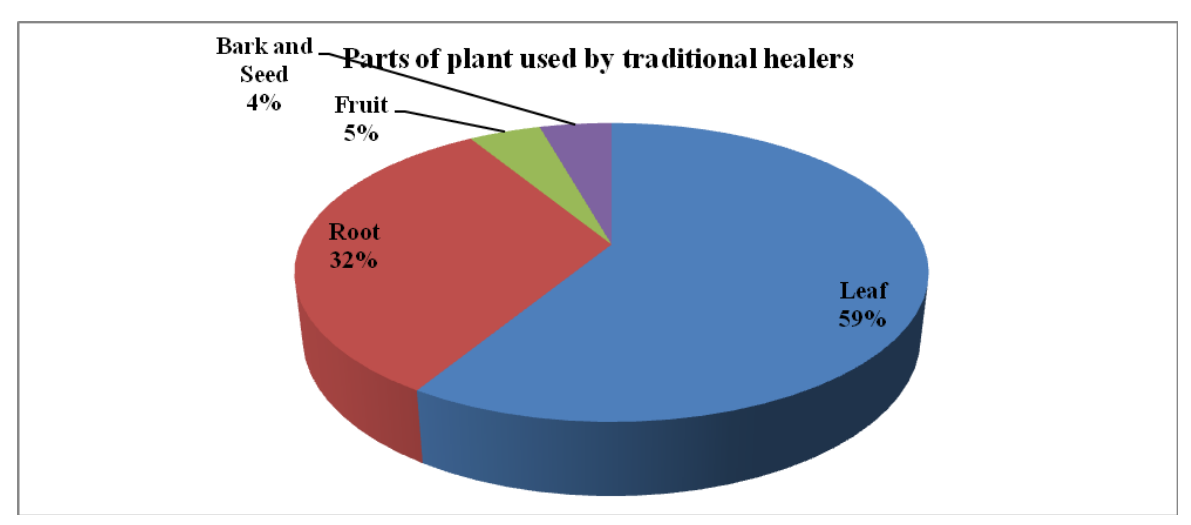

Figure 1: Major parts of the medicinal plants used in the study area

The results of study depicted that the major part of the medicinal plants were leaf, root, fruit, bark and seed with proportion of 40 (58.8\%), 22 (32.4\%), 3 (4.4 $\%)$ and $2(2.9 \%)$, respectively in the study area (Figure 1$)$.

\section{Harvesting technique of medicinal plants}

Different unscientific harvesting techniques of medicinal plants were practiced by traditional healers with equal proportion of the whole removal, 23 (33.8\%) 
followed by uprooting and debarking, 22 (32.4\%). Abnormal harvesting techniques are the major threatens for conservation of medicinal plants in the study area (Table 5).

Table 5: Harvesting technique of medicinal plants in Melkabello district from November 2014 to April, 2015

\begin{tabular}{lll}
\hline Harvesting methods & Frequency & Percent (\%) \\
\hline Uprooting & 22 & 32.4 \\
Whole Removal & 23 & 33.8 \\
Debarking & 23 & 33.8 \\
Total & 68 & 100 \\
\hline
\end{tabular}

\section{Discussion}

In this study, a total of 68 major considerable medicinal plant species belonging to 55 families were identified and documented in the study area during the study period. The results of the study revealed that Fabaceae, Astraceae and Laminaceae families were represented the dominant families. The finding of the survey was revealed that the majority of the traditional healers rely on indigenous traditional knowledge and locally available materials which was in line with the result of Mirutse Giday et al. (2003).

In this study, different livestock alignments: febrile diseases, "Mich", Blackleg, gastrointestinal parasites infestations, external injuries, reproductive insufficiency and others diseases as well as disease conditions were treated by the medicinal plants in study area. This agrees with Reshid et al. (2010) in Bangladesh who reported that the most common cattle ailments observed were fever, meningitis, gastrointestinal disorders, and helminthiasis. This might be due to similarity in climatic condition and the purpose for which the medicinal plants used in both study areas. The result was also consistent with Tadesse Birhanu and Dereje Abera (2015) who reported the dominant plant species at selected districts of Horro Gudurru Wollega Zone, western Ethiopia.

The finding of this study was indicated that the habit of collected medicinal plants herb, tree, shrub and climber were identified with that herb, 39.7\% 
was dominant in the study area. This result was agreed with study conducted by Tilahun Teklehaymanot and Mirutse Gidey (2007) who reported the dominance of herbs, $52 \%$ in Northwest Ethiopia. Other similar study that was conducted by Tamiru Tessema et al. (2001) in northern Ethiopia indicated that high percentage of herbs. This finding could be an indication of abundance of herbs around rain fall areas. However, the dominance of herbs in the identified medicinal plants could have a negative implication since their growth could easily be hampered by recurrent drought which is common in the studied sites this fact was in accordance with Winfred et al. (2012) in Kenya and Ugyen et al. (2011) in Bhutan which stated that removing a large proportion of herb species in one year is likely to have a significant impact on the species resiliency.

The results of the study indicated that the majority of the medicinal plants which used for medicinal value by the traditional healers were obtained from wild and less commonly also acquired from both wild and cultivated. So the present finding was agreed with the previous finding of Tadesse Birhanu et al. (2014) who reported that most of the medicinal plants were collected from the wild (68\%) and others were from home gardens (32\%) in East Wollega Zone, western Ethiopia. The present study also showed 53 (77.9\%) of medicinal plants exposed to continuous extraction from the wild and substantial loss of their habitats and resulted decline of many highly valuable medicinal plant species in the study area due to difficulty of management and control. This finding also close related to Ugyen et al. (2011) who stated that because of the high price and increased demand on traditional medicines; the wild species are hunted illegally and are traded across the borders. This might be due to the level of forest staff in rural districts was insufficient to manage or control the vast forest areas, which is made even more difficult by the rough undulating impassable terrain of the country.

The finding of this study was showed that majority of the plant's parts used to treat livestock aliments were leaf, root, fruit bark and seed with highest proportion of leaf $40(58.8 \%)$ and with least proportion of bark and seed 2 $(2.9 \%)$ as used medicinal value in the study area which was in line with the result of Tadesse Birhanu et al. (2014) that was done in eastern Wollega Zone and Tilahun Teklehymanot (2013) which was conducted in Tigray region who stated that the widely used plant part for the preparation of the remedies was leaves. Such wide harvesting of leaves for traditional medicine compared to roots in the study area which are important for survival of plants has a less 
negative influence on the survival and continuity of useful medicinal plants and hence does not affect sustainable utilization of the plants.

The study also showed that there were different unscientific harvesting techniques of medicinal plants which was practiced by traditional healers with equal proportion of whole cutting and debarking, 23 (33.8\%) followed by uprooting, 22 (32.4\%).This study finding was in concurrence with Winfred et al. (2012) in Kenya which stated that some of the most destructive methods employed by the practitioners while harvesting medicinal plants were: total debarking, uprooting of whole plants and whole cut. On the other hand, uprooting directly related with herb, trees and shrub are more prone to total debarking and climbers are exposed whole cut. Specially uprooting is one of the poor harvesting methods causes danger of genetic erosion. The debarking of the plants may result into slow death of the whole plant due to the interruption of photosensitization. Similarly, the study was conducted by Edwards (2001) which indicated in appropriate harvesting was interfere with life cycle of medicinal plants.

The most commonly used administration routes of medicine were oral, 48 (70.6\%), topical, 12 (17.6\%), both oral and topical 5 (7.4\%), and aerosol 3(4.4\%). This finding agrees with ethno-botanical study conducted in Tigray region by Tilahun Teklehymanot et al. (2013)who reported that about 20(64.5\%) species of the medicinal plants were taking by oral, about $8(25.8 \%)$ species of medicinal plants were taking by dermal and the rest $3(9.7 \%)$ were taken both by oral and dermal mode of application. The finding was showed that the highest mode rout administration of these medicinal plants were oral which is in line with the report of Teklay Abraha et al. (2013)that reported the routes of administration are oral (65\%), followed by topical (15\%) in Tigray regional state of Ethiopia. The choice of oral administration may be related to the use of some solvents or additives (milk, butter, alcoholic drinks, boiled coffee, and food) that are commonly believed to serve as a vehicle to transport the remedies. The additives are also important to minimize discomfort, improve the taste and reduce adverse effects such as vomiting and diarrhea, and enhance the efficacy and healing conditions (Kebu Balemie et al., 2004).

The present finding indicated that majority of the plant remedies were prepared from fresh material of the plants which accounted (82.5\%) followed by fresh/ dry $(17.5 \%)$ which in lined with the work conducted by Tadesse Birhanu et al. 
(2014) at East Wollega Zone and Gebre Medhin Gebrezgabiher et al. (2013) in Tigray region Gemad district who stated the common dominant preparation mode was fresh form (Mirutse Giday et al., 2003; Tadesse Birhanu and Dereje Abera, 2015).

\section{Conclusion}

In general, the present study identified and documented about68 medicinal plant species belonging to55families of ethno-veterinary medicinal plants. The plants were mainly collected from the wild based on the consultation of traditional healers. Agricultural expansion and overgrazing were found to be the main threats for the medicinal plants. This study also showed the largest numbers of remedies of the medicinal plants were used to treat livestock diseases and disease conditions. Thus, the traditional healers and modern health professionals should be integrated to combat diseases via improving veterinary services. Moreover, further scientific research should be needed to determine the safety, toxicity and standardize dose.

\section{Acknowledgements}

The authors would like to thank Wollega University, School of Veterinary Medicine, Local Administration Authorities, study participants and all individuals who render help during the study period.

\section{References}

Abraha, T., Balcha A. and Giday, M., 2013. An ethnobotanical study of medicinal plants used in Kilte Awulaelo District, Tigray Region of Ethiopia. J. Ethnobiol. Ethnomed., 9:65.

Birhanu, T., Gadisa, M., Gurmesa, F. and Abda, S., 2014. Survey of ethno veterinary medicinal plants at selected woredas of East Wollega Zone, Western Ethiopia. J. Biol. Agric. Healthcare., 4(17), 97-105.

Birhanu, T. and Abera, D., 2015. Survey of ethno veterinary medicinal plants at selected districts of Horro Gudurru Wollega Zone, Western Ethiopia. Afr. J. Plant Sci., 9 (3), 185-192.

CSA, 2009. Central Statistical Agency: The 2002/2003 Ethiopian Agricultural Enumeration (ESAE), Executive Summary, May 2009. Addis Ababa, Ethiopia.

Ethiop. Vet. J., 2016, 20 (2), 1-15 
Edwards, S., 2001. The ecology and conservation status of medicinal plants in Ethiopia. In: Conservation and sustainable use of medicinal plants in Ethiopia, 46-55, (Medhin Zewdu and Abebe Demissie, eds.), Proceedings of the National workshop on Biodiversity Conservation and Sustainable use of Medicinal Plants in Ethiopia. IBCR, Addis Ababa, Ethiopia, pp 61-69.

Giday, M., Asfaw, Z., Elmqvist, T. and Woldu, Z., 2003. An ethnobotanical study of medicinal plants used by the Zay People in Ethiopia. J. Ethnopharmacol., 85(1), 43-52.

Hedberg, I., Kelbessa, E., Edwards, S., Demissew, S. and Persson, E., 2006. Gentianaceae to cyclocheiaceae. In: Flora of Ethiopia and Eritrea vol.5. The national herbarium Addis Ababa, Ethiopia and Uppsala, Sweden.

Martin, G.J., 1995. Ethnobotany: A method Manual. Chapman and Hall, London. Medicine in Ethiopia: Prospective and Development Efforts. In: Ethiopian Pharmaceutical Association. 45-53 (Tamirat Ejigu, edn.) Silver Jubilee Anniversary, Special Issue. Addis Ababa, Ethiopia. pp 265-270.

Mengistu, A.K., 2004. The effect of herbal preparations on Staphylococcus aureus and Streptococcus agalactiae isolated from clinical bovine mastitis (Unpublished MSC thesis Faculty of veterinary medicine, AAU).

NMSA, 2013. National Meteorological Services Agency: Monthly report on temperature and rainfall distribution for Eastern Wollega Zone, Regional Metrological Office, Nekemte, Ethiopia.

Rashid, S., Rabiea, T., Khokon, C., Ghosh, R. and Jahan, M., 2010. An ethno veterinary survey of medicinal plants used to treat cattle diseases in Birishiriarea Netrakona Bangladesh, 4, 10-13.

Teklehaymanot, T. and Gidey, M., 2007. Ethno botanical study of medicinal plants used by people in Zegie peninsula, north western Ethiopia. J. Ethnobiol. Ethnomed., 3, 12.

Tessema, T., Gidey, M. and Aklilu, N., 2001. Stacking and information on the medicinal plants of Ethiopia. In National Biodiversity strategy and action plan project Medicinal plant Team, Addis Ababa: IBDA.

Ugyen, A., Phurpa, W., and Annette, O., 2011. Vulnerable medicinal plants and the risk factors for their sustainable use in Bhutan. J. Med. Plant Res., 1, 1-20.

Winfred, M., Daniel, K. and Joyce, M., 2012. Conservation status and use of medicinal plants by traditional medical practitioners in Machakos district, Nairobi, Kenya, 8:1-3. 
Yigezu, Y., Haile, D. and Yenet, W., 2014. Ethno veterinary medicines in four districts of Jimma zone, Ethiopia: A cross sectional survey for plant species and mode of use. BMC Vet. Res., 10, 76. 